\title{
Evaluation of Radioactivity Level and Its Radiological Impact in Soil Samples Around Transmission Company of Nigeria
}

\author{
Abiodun Odunlami Adegunwa ${ }^{1, *}$, Odunayo Timothy Ore ${ }^{2}$, Tobi Ezekiel Osadare ${ }^{1}$, \\ Victoria Olamide Ogunlowo ${ }^{1}$ \\ ${ }^{1}$ Department of Pure and Applied Chemistry, Osun State University, Osogbo, Nigeria \\ ${ }^{2}$ Department of Chemistry, Obafemi Awolowo University, Ile-Ife, Nigeria
}

Email address:

abiodun.adegunwa@uniosun.edu.ng (A. O. Adegunwa)

*Corresponding author

\section{To cite this article:}

Abiodun Odunlami Adegunwa, Odunayo Timothy Ore, Tobi Ezekiel Osadare, Victoria Olamide Ogunlowo. Evaluation of Radioactivity Level and Its Radiological Impact in Soil Samples Around Transmission Company of Nigeria. Radiation Science and Technology. Vol. 5, No. 4, 2019, pp. 41-46. doi: 10.11648/j.rst.20190504.12

Received: October 7, 2019; Accepted: October 29, 2019; Published: November 5, 2019

\begin{abstract}
The aim of this study is to estimate the activity concentrations and radiological assessment of soils around hightension cables, Transmission company of Nigeria, Osogbo, Nigeria. Surface and control soils were obtained around the hightension cables and from areas far away from the sampling points, respectively. Their radioactivity levels were determined using gamma ray spectrometer. The results showed that the mean activity of the identified radionuclides, ${ }^{40} \mathrm{~K},{ }^{238} \mathrm{U}$ and ${ }^{232} \mathrm{Th}$ are $223.59 \pm 11.98,15.39 \pm 1.95$ and $4.54 \pm 0.28 \mathrm{~Bq} / \mathrm{kg}$ respectively, in the studied soils while the control soils exhibited activity concentrations of ${ }^{40} \mathrm{~K},{ }^{238} \mathrm{U}$ and ${ }^{232} \mathrm{Th}$, as $6.22 \pm 0.34,11.58 \pm 1.55$ and $0.50 \pm 0.03 \mathrm{~Bq} / \mathrm{kg}$ respectively. The radiological indices, ADR (absorbed dose rate), AED (annual effective dose equivalent), $H_{\text {in }}$ (internal hazard index), $H_{\text {ex }}$ (external hazard index), AGDE (annual gonadal dose equivalent), $\mathrm{I}_{\gamma \mathrm{r}}$ (representative gamma index) and $\mathrm{Ra}_{\mathrm{eq}}$ (radium equivalent) have values of 19.65 $\mathrm{nGy} / \mathrm{hr}, 0.17 \mathrm{mSv} / \mathrm{yr}, 0.14 \mathrm{~Bq} / \mathrm{kg}, 0.10 \mathrm{~Bq} / \mathrm{kg}, 140.77 \mu \mathrm{svy}^{-1}, 0.30$ and 39.64 respectively. These results revealed that the studied soils exhibited low gamma radiation. Long-term exposure to these radionuclides could pose health threats and is therefore discouraged.
\end{abstract}

Keywords: Activity Concentration, Gamma Ray Spectrometer, High-tension Cable, Powerline, Radiation, Transmission Company

\section{Introduction}

Since inception, man has always been exposed to radiation from naturally occurring radionuclides with long half-lives, such as ${ }^{40} \mathrm{~K},{ }^{238} \mathrm{U}$, and ${ }^{232} \mathrm{Th}$. As a result of their radioactivity, those radionuclides cause natural radiation [1]. These radionuclides are termed primordial radionuclides such as uranium ${ }^{238} \mathrm{U}$, thorium ${ }^{232} \mathrm{Th}$, and non-decay series of potassium ${ }^{40} \mathrm{~K}$ [2]. Natural background radiation, which is equivalent to $2.4 \mathrm{mSv}$ per person, has been known to makes up approximately $80 \%$ of the total radiation dose a person is exposed in a year [3]. Estimated exposure to natural radiation from naturally occurring radionuclides has become environmental concern to the public and national authorities due to its deleterious effect on humans. The levels of these doses have been observed to increase due to some certain anthropogenic activities thereby enhancing the natural background radiation.

Many industrial and human activities have contributed significantly to elevated levels of radionuclides in surface and subsurface soils when compared to those contributed from geogenic or natural processes [4].

Man-made terrestrial components are majorly due to the deposition of radioactive fallout, $\mathrm{x}$-ray photography and radiation emission from high tension cables among others. Soil is acting both as a source of radiation exposure to humans and also as a medium of migration for the transfer of radionuclides to groundwater and biological systems [5]. Soil 
is one of the major sources of radiation exposure to a population via the transfer of radionuclides into the environment [6]. The knowledge of radionuclides distribution in soil plays an important role in radiation protection because they are not uniformly distributed in soil.

Pollution implication of radionuclides even at extremely low concentration could result in long-term cumulative health effects and this has been a major cause of concern all over the world. This concern has increase by their persistence in the soil and their tendency to bioaccumulate, move along the food chain and water cycle, and also poison soil microorganisms [7]. However, high exposure level may be harmful for people residing in regions where these human activities are pronounced. Radionuclides are carried to the soil by rain during rock disintegration. Radiation can cause sterility, making reproduction impossible. Excessive exposure to ionizing radiations has been known to cause various long-term health hazard like cancer, mental disorder, genetic mutation, etc., to workers and the general public [8]. It can also cause mutations in developing embryos, which are usually detrimental or even fatal [9].

The aim of this study is to determine natural $\left({ }^{226} \mathrm{Ra},{ }^{232} \mathrm{Th}\right.$, ${ }^{40} \mathrm{~K}$ ) radioactivity levels in soil collected from different points around the vicinity of high-tension cables electricity distribution center in Osogbo, Nigeria. Also, the average radium equivalent activity $\left(\mathrm{Ra}_{\mathrm{eq}}\right)$, representative level index (I $\gamma \mathrm{r})$, the external hazard index (Hex), the total absorbed dose rate (ADR) and the annual effective dose equivalent (AED) were calculated and compared with the results in literature.

\section{Materials and Methods}

\subsection{Study Area, Sampling, Sample Storage and Preparation}

The study area (Figure 1) is within Osogbo, the capital of Osun State. Osogbo is a city in South-Western Nigeria located on latitude $7^{\circ} 78^{\prime} 27^{\prime \prime} \mathrm{N}$ and longitude $4^{\circ} 54^{\prime} 18^{\prime \prime} \mathrm{E}$. The city is situated within the tropic rainforest zone in Nigeria.

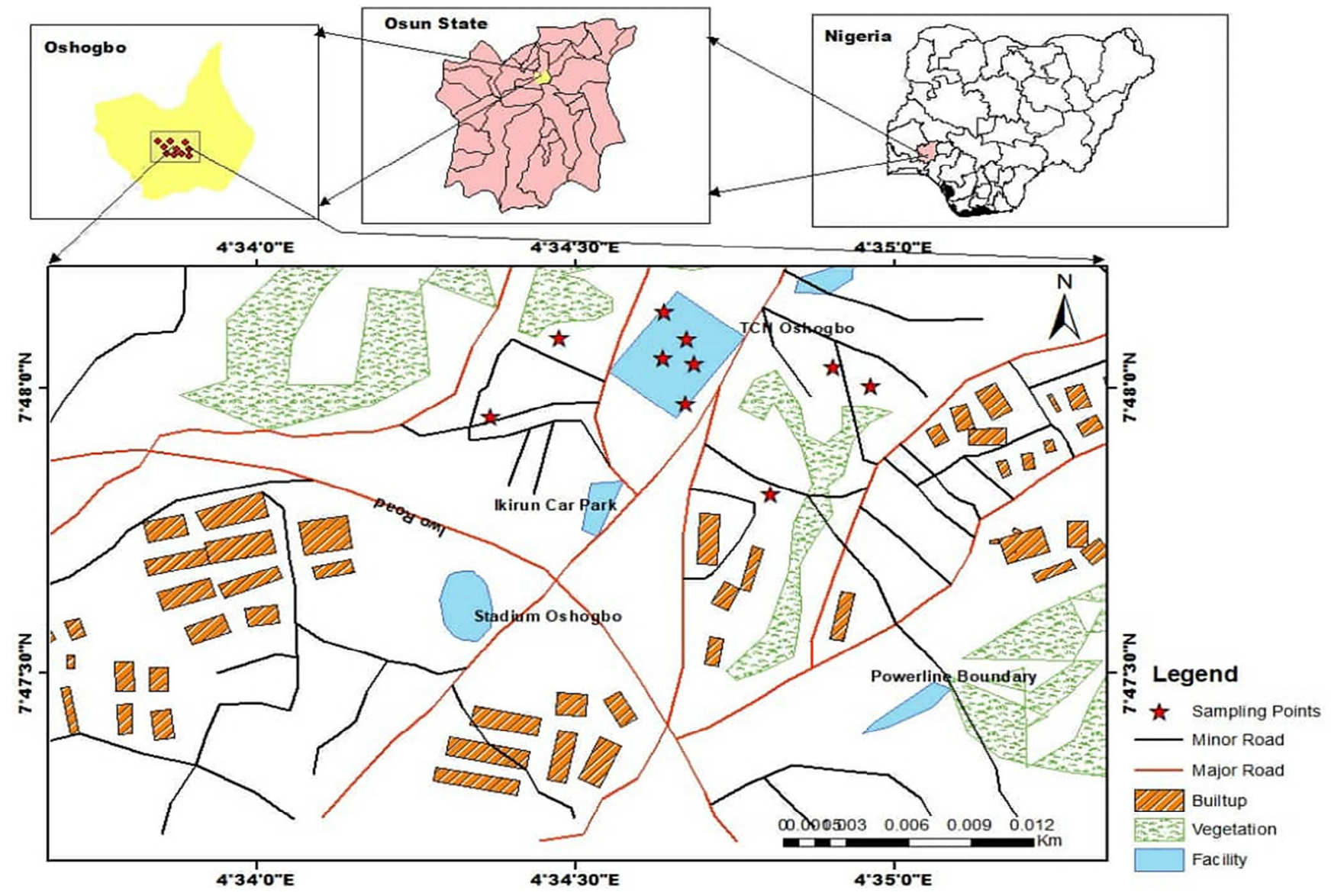

Figure 1. Map of the Study Area showing the Sampling Locations.

Surface soil samples were collected from eight (8) different areas in and around Transmission Company of Nigeria (TCN), Osogbo, Nigeria while the two control soil samples were taken from areas where there are little or no anthropogenic activities within the locality.

The samples were collected by scooping the soil samples into airtight containers labeled according to the name of the area from which the samples were collected and transported into the laboratory for analysis.

The surface soil samples were air-dried; rocks and pebbles were removed before pulverization using a mortar and pestle. The pulverized soil samples were then passed through a 500 $\mu \mathrm{m}$ filter sieve to achieve uniform particle size. Sample grinding continued until at least $90 \%$ of the original sample 
passed through the sieve before radioactivity determination.

The dried homogenized samples were then weighed and transferred into uncontaminated empty cylindrical plastic containers of uniform sizes wrapped with a masking tape. The samples were weighed and stored for a minimum period of 30 days to allow daughter products to come into radioactive secular equilibrium with their parents ${ }^{226} \mathrm{Ra}$ and ${ }^{232} \mathrm{Th}$.

The counting of radioactivity was carried out using a lead shield $76 \mathrm{~mm}$ by $76 \mathrm{~mm} \mathrm{NaI}$ (Tl) detector crystal (model 802 series, Canberra Inc) coupled to a Canberra series 10plus multichannel analyzer (MCA) (model 1104) through a preamplifier.

\subsection{Experimental Method for $\gamma$-spectroscopy}

Natural radioactivity concentrations of each sample collected were calculated by counting approximately 10 hours using $\mathrm{NaI}(\mathrm{Tl})$ scintillation detector based on a gamma spectrometer system. The gamma spectrometer consists of a Canberra $7.6 \mathrm{~cm}$ by $7.6 \mathrm{~cm} \mathrm{NaI}$ (TI) detector coupled with a Canberra series 10 plus Multichannel Analyzer (MCA) through a preamplifier base. At the base and side surfaces of the detector, $5 \mathrm{~cm}$ thick lead layers were used to minimize the contribution of the surrounding radiation. The energy calibration and the relative efficiency calibration of the gamma spectrometer were determined with standard calibration material (IAEA-375). Activity concentrations, corresponding prominent photo peaks observed in the spectra of the samples at various energies were identified as those of the radionuclides in the natural decay series of ${ }^{238} \mathrm{U}$ and ${ }^{232} \mathrm{Th}$, and the non-series ${ }^{40} \mathrm{~K}$.

\subsection{Gamma Radiation Parameters}

\subsubsection{Evaluation of Radium Equivalent $\left(R a_{e q}\right)$}

Radium equivalent activity $\left(\mathrm{Ra}_{\mathrm{eq}}\right)$ is a commonly utilized hazard marker as it evaluates and predicts exposure to radiation to living organisms in terms of radiation dose. Radium equivalent activity is indexes that represent the specific activity of ${ }^{40} \mathrm{~K},{ }^{232} \mathrm{Th}$ and ${ }^{226} \mathrm{Ra}$ by a single quantity which takes into consideration the hazard of radiation associated with them.

The equation is given in $\mathrm{Bqkg}^{-1}$, the $\mathrm{Ra}_{\mathrm{eq}}$ expression is below:

$$
\mathrm{Ra}_{\mathrm{eq}}=0.077 \mathrm{~A}_{\mathrm{K}}+\mathrm{A}_{\mathrm{Ra}}+1.43 \mathrm{~A}_{\mathrm{Th}}
$$

This is an assumption that $4810 \mathrm{Bqkg}^{-1}$ of ${ }^{40} \mathrm{~K},{ }^{259} \mathrm{Bqkg}^{-1}$ of ${ }^{232} \mathrm{Th}$ and ${ }^{370} \mathrm{Bqkg}^{-1}$ of ${ }^{226} \mathrm{Ra}\left({ }^{238} \mathrm{U}\right)$ produce the same gamma dose.

\subsubsection{Absorbed Dose Rate (ADR)}

This measures the exposure to human body in order to determine the amount of radiological hazards. The absorbed dose rate at $1 \mathrm{~m}$ above the ground (in $\mathrm{nGyh}^{-1}$ by $\mathrm{Bqkg}^{-1}$ ) was calculated using the expression:

$$
\mathrm{ADR}=0.462 \mathrm{C}_{\mathrm{Ra}}+0.604 \mathrm{C}_{\mathrm{Th}}+0.0417 \mathrm{C}_{\mathrm{K}}\left(\mathrm{nGyh}^{-1}\right)
$$

where $\mathrm{C}_{\mathrm{Ra}}, \mathrm{C}_{\mathrm{Th}}$ and $\mathrm{C}_{\mathrm{K}}$ are the activity concentrations $\left(\mathrm{Bqkg}^{-1}\right)$ for ${ }^{226} \mathrm{Ra},{ }^{232} \mathrm{Th}$ and ${ }^{40} \mathrm{~K}$ in soil samples, respectively.

\subsubsection{Annual Effective Dose Equivalent (AED)}

The mean annual evaluated effective dose equivalent (AED) taken by a person was figured out employing a transformation factor of $7 \times 10^{-1} \mathrm{SvGy}^{-1}$, which was used to transform the absorbed dose rate to humankind effective dose equivalent with an outdoor occupancy of $20 \%$.

$$
\begin{gathered}
\mathrm{AED} \text { (outdoor) }(\mu \mathrm{Sv} / \mathrm{y})=\operatorname{ADR}\left(\mathrm{nGy} \mathrm{h}^{-1}\right) \times 0.7 \mathrm{~Sv} \mathrm{~Gy}^{-1} \times 8760 \\
\text { hours } \times 0.2 \times 10^{-3}
\end{gathered}
$$

\subsubsection{Internal and External Hazard Index}

The internal exposure to ${ }^{222} \mathrm{Rn}$ and its hazardous progenies to the respiratory organs is controlled by the internal hazard index $\left(\mathrm{H}_{\mathrm{in}}\right)$, [3] as described below:

$$
\mathrm{H}_{\mathrm{in}}=\left(\mathrm{A}_{\mathrm{Ra}} / 185+\mathrm{A}_{\mathrm{Th}} / 259+\mathrm{A}_{\mathrm{K}} / 4810\right) \leq 1
$$

The $A_{R a}$ is replaced by $A_{U}$ in the calculations. It may be noted that ${ }^{238} \mathrm{U}$ is replaced by the decay product ${ }^{226} \mathrm{Ra}$, although there may be disequilibrium between ${ }^{238} \mathrm{U}$ and ${ }^{226} \mathrm{Ra}$. It is given as 1.03 by [3]. The factors which determine the exposure rate of an individual are the concentration of radionuclides in the nuts and the time spent outdoors [10]. A widely used hazard index reflecting external exposure called the external hazard index $\mathrm{H}_{\mathrm{ex}}$ is defined as follows:

$$
\mathrm{H}_{\mathrm{ex}}=\left(\mathrm{A}_{\mathrm{Ra}} / 370+\mathrm{A}_{\mathrm{Th}} / 259+\mathrm{A}_{\mathrm{K}} / 4810\right) \leq 1[3]
$$

\subsubsection{Annual Gonadal Dose Equivalent (AGDE)}

The gonads, the active bone marrow and the bone surface cells are considered as the organs of interest [3]. Therefore, the Annual Gonadal Dose Equivalent (AGDE) for the residents of the study area due to specific activities of ${ }^{226} \mathrm{Ra}$, ${ }^{232} \mathrm{Th}$ and ${ }^{40} \mathrm{~K}$ is calculated using the following relation:

$$
\operatorname{AGDE}\left(\mu \mathrm{Svy}^{-1}\right)=3.09 \mathrm{~A}_{\mathrm{Ra}}+4.18 \mathrm{~A}_{\mathrm{Th}}+0.314 \mathrm{~A}_{\mathrm{K}}[11]
$$

\subsubsection{Representative Gamma Level Index $\left(I_{\gamma r}\right)$}

The representative gamma radiation level index, $I_{\gamma r}$, is generally used to estimate the level of toxicity of radionuclides in the human body when there is exposure to a level of external annual effective doses of gamma radiations decayed from radioactive isotopes in soils. This additional hazard index also called radioactivity level index was calculated by using the formula below [12]:

$$
\mathrm{I}_{\gamma \mathrm{r}}=\mathrm{A}_{\mathrm{Ra}} / 150 \mathrm{Bqkg}^{-1}+\mathrm{A}_{\mathrm{Th}} / 100 \mathrm{Bqkg}^{-1}+\mathrm{A}_{\mathrm{K}} / 1500 \mathrm{Bqkg}^{-1}
$$

The value of $I_{\gamma \mathrm{r}}$ must be below 1 (unity) to keep the radiation hazard insignificant.

\section{Results and Discussion}

\subsection{Activity Concentration}

The activity concentrations ${ }^{40} \mathrm{~K},{ }^{226} \mathrm{Ra}$ and ${ }^{232} \mathrm{Th}$ expressed in $\mathrm{Bq} / \mathrm{kg}$ for soil samples obtained from high tension power line area, Osogbo are presented in Table 1 while those of the 
control samples are presented in Table 2. The samples showed that ${ }^{40} \mathrm{~K}$ has the highest activity value compared to the other radionuclides in the study area. The average activity concentration of the radionuclides in the soil samples was in the order ${ }^{40} \mathrm{~K}>{ }^{226} \mathrm{Ra}>{ }^{232} \mathrm{Th}$. The values of ${ }^{40} \mathrm{~K}$ ranged from $34.40 \mathrm{~Bq} / \mathrm{Kg}$ to $527.53 \mathrm{~Bq} / \mathrm{Kg}$ with an average of 223.59 $\mathrm{Bq} / \mathrm{Kg}$ while the values of ${ }^{226} \mathrm{Ra}$ ranged from 3.36 to 25.20 $\mathrm{Bq} / \mathrm{Kg}$ with an average of $15.39 \mathrm{~Bq} / \mathrm{Kg}$ and the values of ${ }^{232} \mathrm{Th}$ ranged from 0.01 to $13.33 \mathrm{~Bq} / \mathrm{Kg}$ with an average of $4.54 \mathrm{~Bq} / \mathrm{Kg}$ for all the samples. For the control soil samples, the mean activity concentrations of ${ }^{40} \mathrm{~K},{ }^{232} \mathrm{Th}$ and ${ }^{238} \mathrm{U}$ are $6.22 \pm 0.34 \mathrm{~Bq} / \mathrm{Kg}, 0.50 \pm 0.05 \mathrm{~Bq} / \mathrm{Kg}$, and $11.50 \pm 0.01 \mathrm{~Bq} / \mathrm{Kg}$ respectively.

Generally, high values of ${ }^{40} \mathrm{~K}$ were observed in the soil samples used for this study. This observed high content of ${ }^{40} \mathrm{~K}$ in the soil samples may be as a result of geological formation underlying the study area. The mean value of ${ }^{40} \mathrm{~K}$ estimated was relatively higher than that $370 \mathrm{~Bq} / \mathrm{Kg}$ reported by [3] and with other similar work carried out by [13] in a mechanic workshop in Akure, Nigeria. However, the estimated mean value for ${ }^{40} \mathrm{~K}$ were observed to be above 100 $\mathrm{Bq} / \mathrm{kg}$. It was also observed that the mean activity concentrations of the radionuclides in the soil samples around the high tension cables are higher than that of the control soils. This suggests contributions of anthropogenic activities within the area as a result of radiation emission which may have increased level of radionuclides in the soils.

Table 1. Activity concentrations of the identified radionuclides in the soil around high tension cables (Bq/Kg).

\begin{tabular}{llll}
\hline SAMPLES & ${ }^{\mathbf{4 0}} \mathbf{K}$ & ${ }^{\mathbf{2 3 8}} \mathbf{U}$ & ${ }^{\mathbf{2 3 2}} \mathbf{T h}$ \\
\hline A1 & $71.53 \pm 3.91$ & $25.20 \pm 3.13$ & $13.33 \pm 0.81$ \\
A2 & $241.69 \pm 12.97$ & $3.36 \pm 0.49$ & $2.42 \pm 0.15$ \\
B1 & $216.91 \pm 11.65$ & $19.64 \pm 2.35$ & $2.13 \pm 0.13$ \\
B2 & $34.40 \pm 1.87$ & $20.88 \pm 2.68$ & $0.93 \pm 0.06$ \\
B3 & $361.79 \pm 19.43$ & $15.68 \pm 2.00$ & $1.28 \pm 0.08$ \\
B4 & $62.20 \pm 3.37$ & $9.88 \pm 1.40$ & $8.04 \pm 0.49$ \\
C1 & $527.53 \pm 28.04$ & $11.20 \pm 1.42$ & $8.19 \pm 0.50$ \\
C2 & $272.70 \pm 14.62$ & $17.30 \pm 2.12$ & $0.01 \pm 0.00$ \\
MEAN \pm SD & $223.59 \pm 11.98$ & $15.39 \pm 1.95$ & $4.54 \pm 0.28$ \\
\hline
\end{tabular}

Table 2. Activity concentrations of the identified radionuclides in the soils around high tension cables (Bq/kg).

\begin{tabular}{llll}
\hline SAMPLE & ${ }^{\mathbf{4 0}} \mathbf{K}$ & ${ }^{\mathbf{2 3 8}} \mathbf{U}$ & ${ }^{\mathbf{2 3 2}} \mathbf{T h}$ \\
\hline CONTROL 1 & BDL & $15.08 \pm 1.91$ & $0.50 \pm 0.03$ \\
CONTROL 2 & $6.22 \pm 0.34$ & $8.08 \pm 1.19$ & BDL \\
Mean \pm SD & $6.22 \pm 0.34$ & $11.58 \pm 1.55$ & $0.50 \pm 0.03$ \\
\hline
\end{tabular}

\subsection{Radiological Assessment of the Soil Samples}

The radiological assessment of the soils around hightension cables in terms of the absorbed dose rate, annual effective dose equivalent, internal hazard index, external hazard index, annual gonadal dose equivalent, representative level index and radium equivalent is presented in Table 3. The mean absorbed dose rate of the soils is $19.65 \mathrm{nGy} / \mathrm{hr}$. The absorbed dose rate value is less than the population weighted average absorbed dose rate $(60 \mathrm{nGy} / \mathrm{hr})$ in outdoor air from terrestrial gamma radiation [3] and that of the worldwide average of $55 \mathrm{nGy} / \mathrm{hr}$ [14]. The mean annual effective dose equivalent is $0.17 \mathrm{mSv} / \mathrm{yr}$ which is also lower than the range for individual countries $(0.3-0.6 \mathrm{mSv} / \mathrm{yr}$ range) $[15 ; 3]$. World permissive annual dose limit is 1.0 $\mathrm{mSv} / \mathrm{yr}[16]$. The annual dose rate of the radionuclides in the soils around high-tension cables is below the world permissive annual dose limit. This indicates that the exposure to the soils (via inhalation, ingestion or dermal contact) may not lead to respiratory diseases such as asthma and cancer or external diseases such as erythema, skin cancer and cataracts. The internal hazard index is $0.14 \mathrm{~Bq} / \mathrm{Kg}$ while the external hazard index is $0.10 \mathrm{~Bq} / \mathrm{Kg}$ on the average. The values of the indices $\left(\mathrm{H}_{\mathrm{ex}}, \mathrm{H}_{\mathrm{in}}\right)$ must be higher than 1.0 for the radiation hazard to be significant [17]. The internal hazard and external hazard indices of the investigated soils in this study are both less than 1 and so, the radiation hazard is insignificant. The mean annual gonadal dose equivalent of the radionuclides is $140.77 \mu \mathrm{Svy}^{-1}$. This value is less than the world average of $300 \mu \mathrm{Svy}^{-1}$ [3]. The mean representative gamma index value of the studied soils is 0.30 . This value is less than unity and this suggests that the soils exhibit low gamma radiation. The estimated mean value of the $\mathrm{Ra}_{\mathrm{eq}}$ in this present study is $39.64 \mathrm{~Bq} / \mathrm{kg}$. This value is lower than the world average of $370 \mathrm{~Bq} / \mathrm{kg}$ [3]. Sequel upon the radiological assessments obtained for the studied soils, the soils around the hightension cables exhibited low gamma radiation.

Table 3. Radiological Assessment of the Soils Around High-Tension Cables.

\begin{tabular}{|c|c|c|c|c|c|c|c|}
\hline Samples & ADR (nGy/hr) & AED (mSv/yr) & $\mathrm{H}_{\text {in }}(\mathrm{Bq} / \mathrm{Kg})$ & $\mathrm{H}_{\mathrm{ex}}(\mathrm{Bq} / \mathrm{kg})$ & AGDE $\left(\mu \mathrm{svy}{ }^{-1}\right)$ & $\mathbf{I}_{\gamma \mathrm{r}}$ & $\mathbf{R a}_{\mathrm{eq}}$ \\
\hline A1 & 22.67 & 0.19 & 0.20 & 0.13 & 156.04 & 0.34 & 49.76 \\
\hline A2 & 13.09 & 0.11 & 0.07 & 0.06 & 96.38 & 0.20 & 25.43 \\
\hline B1 & 19.40 & 0.17 & 0.15 & 0.10 & 137.70 & 0.29 & 39.38 \\
\hline $\mathrm{B} 2$ & 11.64 & 0.10 & 0.12 & 0.06 & 79.20 & 0.17 & 24.85 \\
\hline B3 & 23.10 & 0.20 & 0.16 & 0.12 & 167.40 & 0.35 & 45.36 \\
\hline
\end{tabular}




\begin{tabular}{llllllll}
\hline Samples & ADR $(\mathbf{n G y} / \mathbf{h r})$ & $\mathbf{A E D}(\mathbf{m S v} / \mathbf{y r})$ & $\mathbf{H}_{\text {in }}(\mathbf{B q} / \mathbf{K g})$ & $\mathbf{H}_{\mathbf{e x}}(\mathbf{B q} / \mathbf{k g})$ & $\left.\mathbf{A G D E}_{(\boldsymbol{\mu} \mathbf{s v y}} \mathbf{- 1}^{\mathbf{1}}\right)$ & $\mathbf{I}_{\boldsymbol{\gamma r}}$ & $\mathbf{R a}_{\mathbf{e q}}$ \\
\hline B4 & 12.01 & 0.10 & 0.09 & 0.07 & 83.66 & 0.18 & 26.16 \\
C1 & 32.11 & 0.28 & 0.20 & 0.17 & 234.48 & 0.50 & 63.53 \\
C2 & 19.37 & 0.16 & 0.15 & 0.10 & 139.12 & 0.29 & 38.31 \\
Mean & 19.65 & 0.17 & 0.14 & 0.10 & 140.77 & 0.30 & 39.64 \\
\hline
\end{tabular}

$\mathrm{ADR}=$ Absorbed dose rate, $\mathrm{AED}=$ Annual Effective Dose equivalent, $\mathrm{H}_{\mathrm{in}}=$ Internal Hazard Index, $\mathrm{H}_{\mathrm{ex}}=$ External Hazard Index. AGDE=Annual Gonadal Dose Equivalent. $\mathrm{I}_{\mathrm{rr}}=$ Representative Level Index and $\mathrm{Ra}_{\mathrm{eq}}=$ Radium equivalent.

\subsection{Comparison of the Radiological Assessment with Similar Studies}

The comparison of the radiological assessment obtained for the soils under study with similar studies is presented in Table 4. The mean absorbed dose rate, the annual effective dose equivalent, the internal hazard index, the external hazard index, the annual gonadal dose equivalent, the representative gamma level index and the radium equivalent observed in this study are all less than those reported by [13] in Measurement of radioactivity levels of oil-contaminated soils around mechanic workshops for environmental impact assessment, and by [18] in Measurement of radioactivity levels in oil impacted soils around petroleum products retailing stations. The relatively higher values of the radiological parameters in these studies could be attributed to the spills emanating from the hydrocarbon products used and sold by the mechanic workshops and petroleum products retailing stations respectively.

Table 4. Comparison of Radiological Assessments with Similar Studies.

\begin{tabular}{llll}
\hline Parameters & This study & {$[\mathbf{1 3}]$} & {$[\mathbf{1 8}]$} \\
\hline $\mathrm{ADR}(\mathrm{nGy} / \mathrm{hr})$ & 19.65 & 63.93 & 62.43 \\
$\mathrm{AED}(\mathrm{mSv} / \mathrm{yr})$ & 0.17 & 0.55 & 0.55 \\
$\mathrm{H}_{\text {in }}(\mathrm{Bq} / \mathrm{Kg})$ & 0.14 & 0.72 & 0.67 \\
$\mathrm{H}_{\mathrm{ex}}(\mathrm{Bq} / \mathrm{kg})$ & 0.10 & 0.37 & 0.38 \\
$\mathrm{AGDE}\left(\mu \mathrm{svy}^{-1}\right)$ & 140.77 & 428.22 & 440.18 \\
$\mathrm{I}_{\gamma \mathrm{r}}$ & 0.30 & 0.92 & 1.22 \\
$\mathrm{Ra}_{\mathrm{eq}}$ & 39.64 & 137.38 & 140.67 \\
\hline
\end{tabular}

\section{Conclusion}

The radioactivity concentrations of ${ }^{40} \mathrm{~K},{ }^{238} \mathrm{U}$ and ${ }^{232} \mathrm{Th}$ in surface soils samples around high-tension cables, powerline area, Osogbo as investigated using gamma ray spectrometer showed that there are low level activities in the studied locations. The average activity concentrations of ${ }^{40} \mathrm{~K},{ }^{238} \mathrm{U}$ and ${ }^{232} \mathrm{Th}$ are $223.59 \pm 11.98,15.39 \pm 1.95$ and $4.54 \pm 0.28$ $\mathrm{Bq} / \mathrm{kg}$ respectively. There was consistency in the pattern observed for the radiological assessment of the soils. The results obtained in the present study showed radiological indices values below the recommended limit proposed by UNSCEAR and other relevant organizations worldwide.

Though, the study showed that the health burden due to gamma radiation from soils on the inhabitant of the area of study is generally low. However, exposure to these radionuclides on a long-term basis could pose serious health risks to humans. It is therefore strongly recommended that power holding companies and transmission stations be relocated or constructed in areas far away from residential areas. The results obtained from this study could serve as reference for future radiological assessment. Continuous monitoring of the radiological assessment of this area for long-term effects of radiation should also be carried out.

\section{References}

[1] Durusoy, A., and Yildirim, M. 2017. Determination of radioactivity concentrations in soil samples and dose assessment for Rize Province, Turkey. Journal of Radiation Research and Applied Sciences, 10 (4), 348-352. doi: 10.1016/j.jrras.2017.09.005.

[2] Carlson, J., E. F. Aronsson, S. O. Hietala, T. Stigbrand, and J. Tennvall. 2003. Tumour therapy with radionuclides: Assessment of progress and problems. Radiotherapy and Oncology 66: 107-17.

[3] United Nations Scientific Committee on the Effects of Atomic Radiation (UNSCEAR). 2000. Sources and effects of ionizing radiation. Report to the General Assembly. New York: United Nation.

[4] Dasaram, B., M. Satyanarayanan, V. Sudarshan, and K. A. Keshav. 2010. Assessment of soil contamination in Patancheru industrial area, Hyderabad, Andhra Pradesh, India. Research Journal of Environmental and Earth Sciences 3: 214-20.

[5] Eke, B. C., N. N. Jibiri, B. C. Anusionwu, C. E. Orji, and H. U. Emelue. 2015. Baseline measurements of natural radioactivity in soil samples from the Federal University of Technology, Owerri, South-East, Nigeria. British Journal of Applied Science and Technology 5 (2): 142-49. doi: 10.9734/BJAST/2015/12171.

[6] Ahmad, N., Jaafar, M. S., Bakhash, M., and Rahim, M. 2015. An overview on measurements of natural radioactivity in Malaysia. Journal of Radiation Research and Applied Sciences, 8 (1), 136-141.

[7] Udousoro, I. I., I. U. Umoren, and E. O. Asuquo. 2010. Survey of some heavy metal concentrations in selected soils in South Eastern parts of Nigeria. World Journal of Applied Science and Technology 2 (2): 139-14.

[8] Avwiri, G. O., and O. E. Esi. 2015. Survey of background ionization radiation level in some selected automobile mechanic workshops in Uvwie LGA Delta State, Nigeria. Journal of Environment and Earth Science 5 (22): 56-60.

[9] World Nuclear Association, WNA. 2003. World Nuclear Association, Nuclear Radiation and Health Effects. WNA naturally-occurring radioactive materials NORM). Energy Sustain Dev.

[10] Avwiri, G. O., and C. P. Ononugbo. 2012. Natural radioactivity levels in surface soil of Ogba/Egbema/Ndoni Oil and Gas Fields. Energy, Science and Technology 4 (2): 92101. 
[11] Arafa, W. 2004. Specific activity and hazards of granite samples collected from the Eastern desert of Egypt. Journal of Environmental Radioactivity 75: 315-22. doi: 10.1016/j.jenvrad.2004.01.004.

[12] Ramasamy, V., S. Senthil, V. Meenakshisundaram, and V. Gajendran. 2009. Measurement of natural radioactivity in beach sediments from North East Coast of Tamilnadu. India, Research Journal of Applied Sciences, Engineering and Technology 1 (2): 54-8.

[13] Adebiyi F. M. and Ore O. T. 2019. Measurement of radioactivity level of oil-contaminated soils around mechanic workshops for environmental impact assessment. Energy Sources, Part A: Recovery, Utilization, and Environmental Effects. 1-10. DOI: 10.1080/15567036.2019.1607932.

[14] Faweya, E. B., F. O. Alabi, and T. Adewumi. 2014. Determination of radioactivity level and hazard assessment of unconsolidated sand and shale soil samples from petroleum oil field at Oredo, Benin, Niger Delta-Nigeria. Archives of Applied Science Research 6 (2): 76-81.
[15] Senthilkumar, B., V. Dhavamani, S. Ramkuma, and P. Philominathan. 2010. Measurement of gamma radiation levels in soil samples from Thanjavur, using $\gamma$-ray spectrometry and estimation of population exposure. Journal of Medical Physics 35: 48-53. doi: 10.4103/0971-6203.55966.

[16] Orgun, Y. N., S. Y. Altinsoy, Y. Sahin, A. H. Gungor, G. Gultekin, Karaham, and Z. Karaak. 2007. Natural and anthropogenic radionuclide in rocks and beach sands from Ezine region, Western Anatolia, Turkey. Applied Radiation and Isotopes 65: 739-47. doi: 10.1016/j.apradiso.2006.06.011.

[17] Diab, H. M., S. A. Nouh, A. Hamdy, and S. A. El-Fiki. 2008. Evaluation of natural radioactivity in a cultivated area around a fertilizer factory. Journal of Nuclear and Radiation Physics 3 (1): 53-62.

[18] E. O. Olalekan and F. M. Adebiyi 2019. Measurement of radioactivity levels in oil impacted soils around petroleum products retailing stations, Petroleum Science and Technology, DOI: 10.1080/10916466.2019.1656240. 